liur J Clin Chem C'lin Biod)em

1995; 33:473 - 478

(i) 1905 Willer de Gruyter \& Co. Berlin - Now York

\title{
Plasma Lipoprotein(a) and Its Relationship with Disease Activity in Patients with Behçet's Discase
}

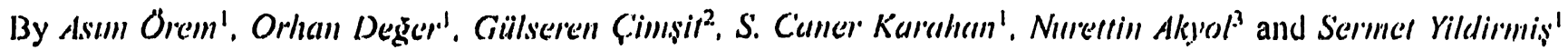 \\ 1 Department of Bicschemistry' \\ 2 Department of Dermantology \\ 3 Dopartiment of Ophthalmolog!'

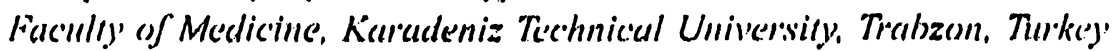

(Received danuary II/April 19, 190)5)

Summary: Behset's discase is characterized by orogenital ulcerations and ocular lesions. Other fealures include arthritis, thrombophlebitis, neurological abnormalitics and skin lesions. The discase is chantaclerized by a relapsing inflammatory process of unknown actiology. Lipoprotcin(ii) is an L.DI_-like particle with a large glycoprotcin cialled apolipoprotein(it) attached to its apolipoprotein B moiety through one or more disulphide bonds. Apolipoprotein(a) is related 10 plasminogen from which the enzyme plasmin, that hydrolyses librin blood clots, is released by tissue plisminogen activators. The unique structural features of $I_{\text {L }} p(a)$ give it the polential for atherogenic and thrombogenic activities. In the present study $35 \%$ of patients with Behsect's discase were shown to have higher Lp(ii) concentrations than the cut-off point $(0.30 \mathrm{~g} / \mathrm{l})$ for atherosclerosis. Plasma $\mathrm{Lp}(\mathrm{a})$ concentrations in the remission period were also found to be lower than during the active period in the same patients (23\% decreatsed). Lp(a) showed significant correlations with acute phase reactants such as erythrocyte sedimentation rate, polymorphonuclear leukocyles and polymorphonuclear leukocyle elastase activity. Therefore, it was concluded that the fluclations of plasma Lp(a) levels with the activity of discasc nay be a contributing risk factor in the development of thrombogenic complications in patients with Behget's disense.

In conclusion, we suggest that plasma $L_{p} p(a)$ concentrations be determined for patients wilh Behged's disease, and that patients with high $\mathrm{L} p$ (a) levels be kept under close controls especially during the active period of the discase, and laken into remission as soon as possible.

\section{Introduction}

Behçet's disease was discovered by Dr: Hulusi Behçet in 1937 and is characterized by oral and genital ulcers and eye inflammation (1). Other features inclucle arthritis, thrombophlebitis, neurological abnormalities and skin lesions (2). The disease affects the arteries and veins. The prectominant histopathological lesion is a vasculitis with the vessel walls and perivascular tissues inliltrated mainly by lymphocytes but also by monocytes, plasma cells and neutrophils $(3,4)$. Thrombosis is one of the vascular manifestations and is seen in about one third of the patients (5). The basis of thrombosis in the pationts is unclear. One of the factors responsible for development of thrombotic events in Behyet's discasc is thought to be association of defective fibrinolysis (6). Many studies have indicaled that reduced librinolysis may be related to decreased endothelial cell production of tissue plasminogen activator and increased concentration of tissue plissminogen activator inhibitor-1 in patients with Behcee's discase $(6,7)$. The change of endothelial eell mediated production and release due 10 vasculitic damage is reported to be related to discasc activity (3).

Lipoprotein(a) [Lp(i1)] described by Berg in 1963 constitutes a newly recognized cardiovascular risk fictor with implications in atherogenic and thrombogenic processes 
(8). The protein moiety of human $L p(a)$ is composed of apolipoprotein $B_{100}$ and the unique, highly glycosylated glycoprotein apolipoprotein(a), which is heterogeneous in size. The tivo protein moieties are linked by disulphide bridges. The apolipoprotein(a) gene is highly homologous to plasminogen and contains multiple repeats of a kringle 4 motif. Apolipoprotein(a) exhibits a striking size polymorphism, with the apolipoprotein(a) isoproteins ranging in size from $M_{\mathrm{r}} 420000$ to 840000 . Inherited in an autosomal codominant fashion, the apolipoprotein(a) isoprotein is an important factor in determining plasma $\mathrm{Lp}$ (a) concentration, with an inverse correlation between the size of the apolipoprotein(a) isoprotein and the plasma $\operatorname{Lp}(\mathrm{a})$ concentration $(9,10)$. Due to the striking similarity of apolipoprotein(a) to plasminogen, $\mathrm{Lp}(\mathrm{a})$ was suggested to act as an interloper in the fibrinolytic system by competing with plasminogen for its binding sites in a dose-dependent manner and inhibiting plasminogen activation $(11,12)$. Therefore, elevated plasma $L p(a)$ levels favour receptor occupancy by the lipoprotein particle and are associated with an increased thrombotic risk. It was reported that plasma $\mathrm{Lp}$ (a) levels are influenced by activity of diseases such as myocardial infarction, and by before and after surgical operation, but are hardly affected by diet, age, sex or treatment with lipid-lowering drugs (13-14).

In view of the above mentioned data, we have suggested that high $\mathrm{Lp}(\mathrm{a})$ levels in patients with Behçet's disease may be a contributing risk factor for the development of thrombotic events (15). In the present study, we aimed to conform our previous data on the expanded patient group and to clarify the relationship of $\mathrm{Lp}$ (a) levels with the disease activity.

\section{Materials and Methods}

The study group included 45 patients with Behçet's disease (male 24 and female 21) with a mean age of 30.8 (age range: 17-55) and 40 healthy volunteers (male 20 and female 20 ) with a mean age of 31.1 (age range: $17-52$ ). The patient group had a mean body mass index (body weight in $\mathrm{kg} / \mathrm{squared}$ height in $\mathrm{m}=\mathrm{kg} / \mathrm{m}^{2}$ height) of $22.8 \pm 5.1$ (mean \pm SD) which was similar to that of the control group of $23.4 \pm 3.9$. All the patients were diagnosed separately by the Internal Medicine, Dermatology and Ophthalmology Departments. The diagnosis of Behçet's disease was made according to the criteria from the International Study Group for Behçet's disease (16). The disease activity was evaluated by physical manifestations such as oral aphthous, genital ulcerations, uveitis and vasculitis and appropriate laboratory investigations such as erythrocyte sedimentation rate, polymorphonuclear leukocytes count, polymorphonuclear leukocyte elastase and $\alpha_{2}$-globulins. Six of the patients had thrombotic complications such as superficial thrombophlebitis, which had superimposed segmental thrombosis areas, laying on the veins of lower extremity. At the time of the study, the patients were receiving neither steroids nor lipid-lowering drugs.

Blood samples of $2.5 \mathrm{ml}$ were drawn in collection tubes with EDTA $(1 \mathrm{~g} / \mathrm{l})$ anticoagulant and of $5 \mathrm{ml}$ in tubes without anticoagulant in the morning by venipuncture after an overnight fast. Anticoagulated blood was divided into two aliquots. Polymorphonuclear leukocyte count, erythrocyte sedimentation rate were determined immediately in one aliquot. The second aliquot and blood sample without anticoagulant, that were allowed to clot for $1 \mathrm{~h}$ at room temperature, were centrifuged at $1500 \mathrm{~g}$ for $15 \mathrm{~min}$ immediately to obtain plasma or serum samples. The serum samples were divided into two aliquots. One was used for determinations of lipids, lipoproteins and protein electrophoresis. The other serum samples for $\mathrm{Lp}$ (a) measurements and plasma samples for polymorphonuclear leukocyte elastase measurement were stored at $-70^{\circ} \mathrm{C}$ until the time of analysis within 3 months.

Serum cholesterol was measured by a cholesterol oxidase enzymatic method, triacylglycerols by a glycerol oxidase enzymatic method, HDL-cholesterol by a cholesterol oxidase enzymatic method in supernatant after precipitation with phosphotungstic acid- $\mathrm{MgCl}_{2}$ and apolipoprotein $\mathrm{A}-\mathrm{I}$ and $\mathrm{B}$ by a turbidimetric immunoassay method [Sera-Pak Immuno Apo A I (Code no: 6821)/Apo B (Code no: 6822), Ames, Canada]. All determinations including immunoassays were carried out by autoanalyzer (Technicon Axon). LDL-cholesterol was calculated by Friedewald formula (17). Serum $L p(a)$ was measured using a commercial anti-apolipoprotein(a) polyclonal capture enzyme-linked immunosorbent assay called TintElize lipoprotein(a) (Catalog no: 610220; Biopool AB, Umea, Sweden) according to the instruction sheet of manufacturer. Using the above described method of analysis for $L p(a)$, intra-assay coefficients of variation of 5.6 and 6.1 percent were obtained at the 0.310 and $0.60 \mathrm{~g} / 1$ of $\mathrm{Lp}(\mathrm{a})(\mathrm{n}=10)$, respectively.

Polymorphonuclear leukocyte elastase was determined by a rapid homogenous immunoactivation (IMAC) assay, using monospecific polyclonal antibodies directed solely against polymorphonuclear leukocyte elastase (18). Test kit was purchased from Merck (D64271 Darmstadt) (cat no.: 113322). Within-run CV\% at $52 \mu \mathrm{g} / 1$ (control plasma) was estimated as $5.2(\mathrm{n}=10)$. Polymorphonuclear leukocytes (granulocytes) were counted by an automated blood counter (MaxM, Coulter), erythrocyte sedimentation rate was determined by classical Westergren method, serum $\alpha_{2}$-globulins by prọtein electrophoresis (Helena Lab).

Plasma concentration of the lipids, lipoproteins and acute phase reactants in the patients and in the controls were compared by the Mann-Whitney U test or Student's t test. Relationships among variables have been assessed by means of Pearson's product-moment (r) correlation coefficients. Wilcoxon test was used to compare the results in the active and inactive periods of the disease.

\section{Results}

The distribution and concentrations of serum $L p(a)$ in patients with Behçet's disease and in control subjects are shown in table 1 and figure 1 . Plasma Lp(a) concentrations in the patients were significantly higher than those of control group $(p<0.05)$. Plasma $\mathrm{Lp}(\mathrm{a})$ concentrations in patients with Behçet's disease were found to be approximately equal to the cut-off point $(0.300 \mathrm{~g} / \mathrm{l})$ for a two-fold risk for atherothrombosis (19) and higher than the cut-off point $(0.18 \mathrm{~g} / \mathrm{l})$ for a twenty-one-fold risk of cerebrovascular disease (20). According to figure $1, \mathrm{Lp}(\mathrm{a})$ levels of sixteen patients (35\%) and six control subjects $(15 \%)$ were found to be higher than the cut-off point for atherosclerosis. $L p(a)$ levels were significantly correlated with apolipoprotein B, polymorphonuclear leukocyte and polymorphonuclear leukocyte elastase levels $(r=0.52, p<0.01 ; r=0.39, p<0.05 ; r=0.36$, $p<0.05$; respectively). The mean serum apolipoprotein A-1. level was significantly lower than in the controls 
Tab. 1 Lipids, lipoproteins and some acute phase reactants in patients with Behçet's disease and in control group.

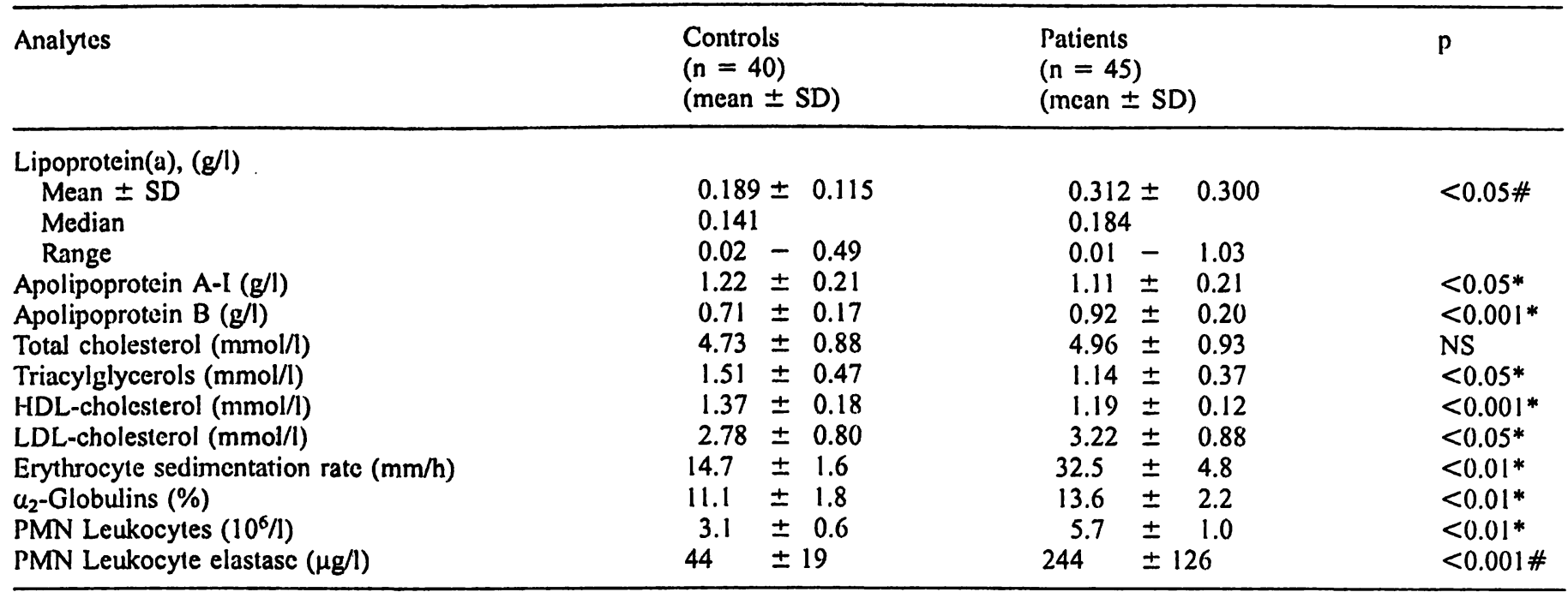

\# According to Mann Whirney $U$ test

$(p<0.05)$. Serum apolipoprotein A-I levels were significantly correlated with HDL-cholesterol levels in the patients $(r=0.36, p<0.05)$. The mean serum apolipoprotein $B$ level of the patients was significantly higher than that of the control group ( $p<0.001)$. Also, triacylglycerols, HDL-cholesterol and LDL-cholesterol levels in the patients showed significant differences from those of the control group apart from total cholesterol levels. Other quantities related to the activity of disease in the patients were found to be significantly higher than those of control subjects (tab. 1). The quantities of the patients with thrombotic complications are shown in table 2 . $\mathrm{Lp}(\mathrm{a})$ and other in these patients were found to be significantly different from the control subjects.

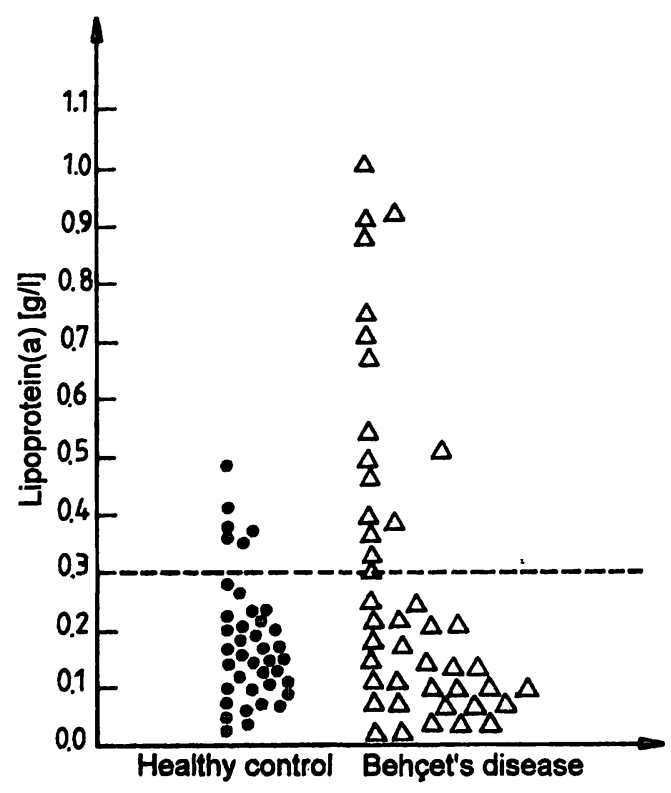

Fig. 1 Serum $\mathrm{Lp}(\mathrm{a})$ concentrations in patients with Behçet's disease and in controls. ( shows controls and $\Delta$ shows patients with Behçet's disease, the dashed lines show the cut-off point for atherosclerosis).
Repeated measurements of the $L p(a)$ and other quantities were made in 10 patients while their disease was active or inactive (tab. 3). During the period of active disease, the mean concentration of $L p(a)$ was $0.326 \mathrm{~g} / \mathrm{l}$ and a significantly decreased mean value of $0.250 \mathrm{~g} / 1$ was obtained when the disease was inactive. Polymorphonuclear leukocytes, polymorphonuclear leukocyte elastase, $\alpha_{2}$-globulins and erythrocyte sedimentation rate showed significant differences between the active and inactive periods of the disease $(p<0.01)$. Plasma concentrations of apolipoprotein A-I and HDL-cholesterol were lower, and apolipoprotein B concentration was higher when the disease was active (data not shown).

\section{Discussion}

Plasma $L p(a)$ levels, which are under genetic control, were highly skewed in the different ethnic groups. It has been reported that the mean $L p(a)$ value of the Turkish population $(0.213 \mathrm{~g} / \mathrm{l})$ had a value near to the cut-off point $(0.30 \mathrm{~g} / \mathrm{l})$ for atheroslcerosis (21). Also, Behçet's disease is most common in the east part of the Mediterranean. The prevalence of the disease is reported to be $8 / 10000$ in Turkey (22). It is well known that high plasma Lp(a) level is associated with an increased incidence of cardiovascular and cerebrovascular disease because of its thrombogenic and atherogenic effects. On the endothelial surface, high plasma levels of $L p(a)$ can interfere with the process of plasminogen-plasmin conversion and result in decreased generation of plasmin and attenuation of clot lysis (23). Moreover, recent reports showed that $L p(a)$ has a direct action on endothelial function and induces the production of tissue plasminogen activator inhibitor by endothelium cells (24). Thus, high $\mathrm{Lp}(\mathrm{a})$ levels may have an association with 
Tab. 2 Anthropometric and analytical quantities of the patients with thrombotic complications

\begin{tabular}{|c|c|c|c|c|c|c|c|}
\hline Patients & Sex & $\begin{array}{l}\text { Age - } \\
\text { (a) }\end{array}$ & $\begin{array}{l}\operatorname{Lp}(a) \\
(g / l)\end{array}$ & $\begin{array}{l}\text { PMN } \\
\text { Leukocytes } \\
\left(10^{9} / 1\right)\end{array}$ & $\begin{array}{l}\text { Erythrocyte } \\
\text { sedimentation } \\
\text { rate } \\
(\mathrm{mm} / \mathrm{h})\end{array}$ & $\begin{array}{l}\text { PMN } \\
\text { Leukocyte } \\
\text { elastase } \\
(\mu \mathrm{g} / \mathrm{l})\end{array}$ & $\begin{array}{l}\alpha_{2} \text {-Globulin } \\
(\%)\end{array}$ \\
\hline $\begin{array}{l}\text { E. V. } \\
\text { Y. K. } \\
\text { M. K. } \\
\text { F. G. } \\
\text { S. S. } \\
\text { I. M: }\end{array}$ & $\begin{array}{l}\delta \\
\delta \\
\delta \\
\delta \\
\delta \\
\delta \\
q \\
q \\
q\end{array}$ & $\begin{array}{l}27 \\
37 \\
32 \\
44 \\
28 \\
42\end{array}$ & $\begin{array}{l}1.03 \\
0.63 \\
0.38 \\
0.33 \\
0.22 \\
0.23\end{array}$ & $\begin{array}{l}5.7 \\
5.8 \\
5.0 \\
5.2 \\
4.4 \\
5.0\end{array}$ & $\begin{array}{l}40 \\
25 \\
35 \\
32 \\
31 \\
38\end{array}$ & $\begin{array}{l}320 \\
288 \\
210 \\
240 \\
178 \\
218\end{array}$ & $\begin{array}{l}13.4 \\
12.8 \\
13.3 \\
12.9 \\
12.5 \\
13.2\end{array}$ \\
\hline $\begin{array}{l}\text { Mean } \\
\text { Median } \\
\text { Range }\end{array}$ & & & $\begin{array}{l}0.46 * * \\
0.33 \\
0.22-1.03\end{array}$ & $\begin{array}{l}5.2^{*} \\
5.0 \\
4.4-5.7\end{array}$ & $\begin{array}{l}33.5^{*} \\
32.0 \\
25-40\end{array}$ & $\begin{array}{l}242^{* *} \\
218 \\
178-320\end{array}$ & $\begin{array}{l}13.5^{*} \\
12.9 \\
12.5-13.4\end{array}$ \\
\hline \multicolumn{8}{|c|}{ Control Group } \\
\hline $\begin{array}{l}\text { Mean } \\
\text { Median } \\
\text { Range }\end{array}$ & & & $\begin{array}{l}0.18 \\
0.14 \\
0.02-0.55\end{array}$ & $\begin{array}{l}3.1 \\
2.9 \\
1.8-4.6\end{array}$ & $\begin{array}{l}14.7 \\
12.5 \\
7-25\end{array}$ & $\begin{array}{l}44 \\
34 \\
21-67\end{array}$ & $\begin{array}{l}11.1 \\
11.2 \\
10.4-12.9\end{array}$ \\
\hline
\end{tabular}

According to Mann-Whitney, U test

${ }^{*} \mathrm{p}<0.05, * * \mathrm{p}<0.01$

Tab. 3 Concentration of $\mathrm{Lp}(\mathrm{a})$ and some acute phase reactants in patients in active and inactive periods in Behçet's disease.

\begin{tabular}{|c|c|c|c|c|c|c|c|c|c|c|}
\hline \multirow[t]{2}{*}{ Patients } & \multicolumn{2}{|l|}{$\begin{array}{l}\mathrm{Lp}(\mathrm{a}) \\
(\mathrm{g} / \mathrm{l})\end{array}$} & \multicolumn{2}{|c|}{$\begin{array}{l}\text { PMN Leukocytes } \\
\left(10^{9} / 1\right)\end{array}$} & \multicolumn{2}{|c|}{$\begin{array}{l}\text { Erythrocyte } \\
\text { sedimentation rate } \\
(\mathrm{mm} / \mathrm{h})\end{array}$} & \multicolumn{2}{|c|}{$\begin{array}{l}\text { PMN } \\
\text { Leukocyte elastase } \\
(\mu \mathrm{g} / \mathrm{l})\end{array}$} & \multicolumn{2}{|c|}{$\begin{array}{l}\alpha_{2} \text {-Globulins } \\
(\%)\end{array}$} \\
\hline & $\begin{array}{l}\text { active } \\
\text { period }\end{array}$ & $\begin{array}{l}\text { inactive } \\
\text { period }\end{array}$ & $\begin{array}{l}\text { active } \\
\text { period }\end{array}$ & $\begin{array}{l}\text { inactive } \\
\text { period }\end{array}$ & $\begin{array}{l}\text { active } \\
\text { period }\end{array}$ & $\begin{array}{l}\text { inactive } \\
\text { period }\end{array}$ & $\begin{array}{l}\text { active } \\
\text { period }\end{array}$ & $\begin{array}{l}\text { inactive } \\
\text { period }\end{array}$ & $\begin{array}{l}\text { active } \\
\text { period }\end{array}$ & $\begin{array}{l}\text { inactive } \\
\text { period }\end{array}$ \\
\hline 1. Ü. Ș. & 0.197 & 0.106 & 5.1 & 2.9 & 21 & 18 & 263 & 168 & 12.8 & 12.4 \\
\hline 2. T. A. & 0.124 & 0.082 & 4.7 & 3.1 & 32 & 21 & 198 & 110 & 13.4 & 12.6 \\
\hline 3. S. K. & 0.521 & 0.387 & 5.5 & 3.6 & 28 & 22 & 273 & 165 & 13.0 & 12.6 \\
\hline 4. N. C.. & 0.138 & 0.092 & 4.9 & 2.6 & 26 & 20 & 235 & 167 & 12.8 & 12.2 \\
\hline 5. Y. K. & 0.637 & 0.551 & 5.8 & 3.1 & 25 & 19 & 288 & 140 & 12.8 & $12.3 \#$ \\
\hline 6. E. S. & 0.121 & 0.057 & 4.7 & 2.5 & 26 & 16 & 180 & 120 & 13.1 & 12.4 \\
\hline 7. A. K. & 0.756 & 0.627 & 6.2 & 4.6 & 36 & 18 & 340 & 210 & 13.6 & 13.1 \\
\hline 8. A. M. & 0.151 & 0.143 & 4.7 & 2.5 & 40 & 27 & 160 & 110 & 13.6 & 13.1 \\
\hline 9. M. K. & 0.388 & 0.279 & 5.0 & 3.1 & 35 & 22 & 210 & 98 & 13.3 & $12.5 \#$ \\
\hline 10. İ. M. & 0.235 & 0.207 & 5.8 & 3.2 & 32 & 18 & 250 & 124 & 13.2 & $12.7 \#$ \\
\hline Median & 0.216 & 0.174 & & & & & & & & \\
\hline Mean & 0.326 & 0.251 & 5.2 & 3.0 & 31 & 20 & 239 & 141. & 13.1 & 12.5 \\
\hline $\mathrm{p}^{*}<$ & 0.01 & & 0.01 & & 0.01 & & 0.001 & & 0.05 & \\
\hline
\end{tabular}

* According to Wilcoxon test

\# The patients with thrombotic complications

decreased fibrinolysis and increased tendency to thrombosis. The basis of thrombotic risk of Behçet's disease is not yet understood. On the other hand, it was reported that the reduced fibrinolytic activity caused by decreased production of tissue plasminogen activator and its increased production by endothelium due to vascular damage may contribute to thrombotic events in the patients $(3,6)$. The mean $\operatorname{Lp}(\mathrm{a})$ level $(0.312 \mathrm{~g} / \mathrm{l})$ in patients with Behçet's disease was found to be similar to the cut-off point. The mean $\mathrm{Lp}$ (a) level of the patients with thrombotic complications was found to be higher than that of the control group (tab. 2). We believe that the cutoff point of $L p(a)$ for atherogenesis differs in the vari- ous ethnic groups because of the many factors affecting atherogenesis (25) as well as the methodology and standardization problems of $\mathrm{Lp}(\mathrm{a})$ measurement. The thrombotic effect of $L p(a)$ via its apolipoprotein(a) part is dose-dependent because of competitive inhibition with plasminogen $(11,12)$. Therefore, $\operatorname{Lp}(a)$ may be more important for its thrombotic properties in Behçet's disease since thrombotic events are more common than atherosclerosis in the disease. Sixteen subjects (35.5\%) among the patients with Behçet's disease had values higher than the cut-off point, and may therefore be at a much greater risk for thrombo-atherogenesis. 
It has been previously reported that the thrombotic tendency and the abnormal fibrinolysis is related to the disease activity (6). Also, $L p(a)$ is known as an acute phase protein and is significantly correlated with acute phase reactants $(13,14)$. The change of plasma $L p(a)$ concentration was confirmed by the present study in patients with Behçet's disease. Plasma $L p(a)$ levels in patients with inactive Behçet's disease were found to be decreased by about $23 \%$ when compared to the active period of disease. The fluctuations of plasma $L p(a)$ levels with the activity of the disease may be a contributing risk factor for thrombogenesis in the active period of the disease. There is no effective lipid-lowering drug for $\operatorname{Lp}(\mathrm{a})$, the treatment of the active Behçet's patients by appropriate drugs for Behçet's disease may play an important role in lowering the plasma $L p(a)$ concentration.

Elastase is primarily located in the azurophil granules and is an active component of the phagocytic system of polymorphonuclear leukocytes $(26,27)$. Perivascular infiltration of polymorphonuclear leukocytes in Behçet's patients is well known. High plasma polymorphonuclear

\section{References}

1. Behçet $H$. Über rezidivierende, aphthöse, durch ein Virus verursachte Geschwüre am Mund, am Auge und an den Genitalien. Dermatol Wochenschr 1937; 105:1152-7.

2. Mousa AM, Marafie AA, Rifai KM, Dajani AI, Mukhar MM. Behçet's disease in Kuwait, Arabia. Scand J Rheumatol 1986; 15:310-32.

3. Hampton KK, Chamberlain MA, Menon DK, Davies JA. Coagulation and fibrinolytic activity in Behçet's disease. Thromb Homeostasis 1991; 3:292-4.

4. Michelson JB, Fridlaender MH. Behçet's disease. Int Ophthalmol Clin 1990; 30:271-8.

5. Kluft C, Michiels JJ, Wijngaards G. Factual or artificial inhibition of fibrinolysis and the occurrence of venous thrombosis in 3 cases of Behçet's disease. Scand J Haematol 1980; 25:423-30.

6. Aitchison R, Chu P, Cater DR, Harris, J, Powell, RJ. Defective fibrinolysis in Behçet's syndrome: significance and possible mechanisms. Ann Rheumatic Disease 1989; 48:590-3.

7. Mishima H, Masuda K, Shimada S, Toki N, Tsushima H, Gocho $\mathrm{M}$. Plasminogen activator activity levels in patient with Behçet's syndrome. Arch Ophthalmol 1985; 105:935-6.

8. Scanu AM, Fless GM. Lipoprotein (a): heterogeneity and biological relevance. J Clin Invest 1990; 85:1705-15.

9. Smith EB, Crosbie L. Does lipoprotein (a) [Lp(a)] compete with plasminogen in human atherosclerotic lesions and thrombi? Atherosclerosis 1991; 89:127-36.

10. Miles LA, Plow EF. Lp(a): an interloper into fibrinolytic system? Thromb Haemostasis 1990; 63:331-5.

11. Miles LA, Fless GM, Levin EG, Scanu AM, Plow EF. A polential basis for the thrombotic risks associated with lipoprotein(a). Nature 1989; 339:301-5.

12. Howard GC, Pizzo SV. Biology of disease. Lipoprotein (a) and its role in atherothrombotic disease. J Clin Lab Invest 1994; 64:373-85.

13. Maeda S, Abe A, Seishima M, Makino K, Nowa A, Kawade $M$. Transient change of serum lipoprotein (a) as an acute phase protein. Atherosclerosis 1989; 78: 145-50. leukocyte elastase levels, which are more specific than erythrocyte sedimentation rate and $\alpha_{2}$-globulins, may represent the activity of vasculitis in patients (28). Positive correlations between plasma $L p(a)$ and polymorphonuclear leukocyte elastase indicate that effects of $\mathrm{Lp}(\mathrm{a})$ on development of thrombotic complications may be related to the activity of the disease. Moreover, $L p(a)$ has an independent effect on the decreased fibrinolysis in patients, and it is also associated with disturbed endothelial functions due to vasculitis.

The decreased concentrations of apolipoprotein A-I, HDL-cholesterol and triacylglycerols found in the patients agree with previous findings $(29,30)$. High apolipoprotein B levels in patients could be explained by the fact that apolipoprotein B presents chiefly in LDL and $\operatorname{Lp}(\mathrm{a})$.

In conclusion, we suggest that plasma $\mathrm{Lp}(\mathrm{a})$ concentrations be determined for patients with Behçet's disease, and the patients with high $L p(a)$ levels be kept under close control, especially during the active period of the disease, and taken into remission as soon as possible.

14. Slunga L, Johason O, Dahlen GH, Erikson S. Lipoprotein (a) and acute phase proteins in acute myocardial infarction. Scand J Clin Lab Invest 1992; 52:95-101.

15. Örem A, Değer O, Memj Ö, Çalışkan K, Çimșrit G. High lipoprotein (a) levels as a thrombogenic risk factor in Behçet's disease. Ann Rheuat Dis 1994; 53:351-2.

16. International Study Group For Behçet's Disease. Criteria for diagnosis of Behçet's disease. Lancet 1990; 335:1078-80.

17. Friedewald WT, Levy RI, Frederickson DS. Estimation of the concentration of low-density lipoprotein in plasma, without use of the preparative ultracentrifuge. Clin Chem 1972; 8:499-502.

18. Fink PC, deBoutemard SV, Haeckel R. Measurement of leukocyte elastase/alpha-1-proteinase-inhibitor complex using a homogeneous and heterogeneous enzyme-immunoassay. J Clin Chem Clin Biochem 1982; 27:869-71.

19. Scanu AM. Lp (a) as a marker for coronary heart disease risk. Clin Cardiol 1991; 14:35-9.

20. Kohn, J. High Lp (a) levels linked to increased risk for stroke. Clin Chem News 1994; 20:7-14.

21. Örem A, Değer O, Önder E, karahan SC, Efe H, Uzunosmanoğlu D. Distribution of plasma lipoprotein (a) levels in healthy Turkish population. Ann Clin Biochem 1994; 31:343-6.

22. Delibaşı E, Turan B, Yücel E, Şaşmaz R, Işımer A, Soysal A. Selenium and Behçet's disease. Biol Trace Element Res $1991 ; 28: 21-5$.

23. Loscalzo J. Lipoprotein (a): a unique risk factor for atherothrombotic disease. Arteriosclerosis 1990; 10:672-9.

24. Ething OR, Hajjar DP, Hajjar RA, Harpel PC, Nachman RL. Lipoprotein (a) regulates plasminogen activator inhibitor-1 expression in endothelial cells. A potential mechanism in thrombogenesis. J Biol Chem 1991; 266:2459-65.

25. Örem A, Değer O, Kulan K, Önder E, Kıran E, Uzunosmanoglu D. Evaluation of $L p(a)[L p(a)]$ as a risk factor for coronary artery disease in Turkish population. Clin Biochem 1995; 28:171-3. 
26. Bieth G. Human neutrophil elastase. In: Robert L, Hornebeek W, editors. Elastin and elastase. Boca Raton: CRC Press, 1989:23-31.

27. Gross V, Schölmerich J, Lesser HG, Salm R, Lausen M, Rückauer $\mathrm{K}$, et al. Granulocyte elastase in assessment of severity of acute pancreatitis. Comparison with acute-phase protein $C$ reactive protein, alpha-1-antitrypsin, and proteinase inhibitor alpha-2-macroglobulin. Dig Dis Sci 1990; 35:97-105.

28. Değer O, Örem A, Akyol N, Bahadır S, Yıldırmıșr S. PMN elastase levels in patients with Behçet's disease. Clin Chim Acta. Accepted for publication.
29. Ohguchi M, Ohno S, Tanaka K, Matsuda H, Sugiura S. Studies on serum lipids in patients with Behçet's disease, Tokyo: University of Tokyo Press, 1982:177-81.

30. Mitamura $T$, Ohno $S$, Aiga $H$, Ohsaka $T$, Iwwasaki $N$, Matsuda $\mathrm{H}$, Matsumiya $\mathrm{H}$. Lipoprotein cholesterol concentration in patients with Behçet's disease. Clin Chim Acta 1988; 175:277-84.

Dr. Asım Örem

KTÜ

Tıp Fakültesi Biyokimya Anabilim Dah 61080, Trabzon

Turkey 